\title{
Published Inconsistencies in Methyl Red and Voges- Proskauer Reactions of Klebsiella pneumoniae
}

\author{
LUCY M. CAMPBELL AND IVAN L. ROTH \\ Department of Microbiology, The University of Georgia, Athens, Georgia 30602
}

Inconsistencies in the results of methyl red and Voges-Proskauer tests of Klebsiella pneumoniae have been published. These inconsistencies result from the unresolved taxonomic position of $K$. aerogenes.

In spite of publications of definitive works, the taxonomic differentiation between the genera Klebsiella and Enterobacter has remained unclear. Rapid and precise identification is necessary in both clinical and pollution microbiology, particularly in view of the apparently ubiquitous distribution of Klebsiella species in both oligotrophic and eutrophic systems.

In studying the occurrence of Klebsiella pneumoniae in the environment, we have discovered a basic discrepancy in the current literature relative to identification, specifically methyl red (MR) and Voges-Proskauer (VP) reactions. $K$. pneumoniae has been reported to be isolated much more frequently than other members of the genus (11), and recently its wide distribution in aquatic systems has been noted (18). Since it is probable that $K$. pneumoniae will gain prominence as an indicator organism, it becomes imperative for investigators to be able to recognize and identify it (Table 1).

Investigation into the current literature revealed that researchers found that high percentages of $K$. pneumoniae isolates were $\mathrm{MR}^{-}$and $\mathrm{VP}^{+}(1,9-11,14-17)$. These isolates came from a variety of sources, including feces, clinical materials, sugar cane and other agricultural products, forest products, and eutrophic and oligotrophic waters. Burrows (4) stated that the coliform group was separated on the basis of the four biochemical tests: indole, methyl red, Voges-Proskauer, and citrate, represented by the mnemonic IMViC. Classically, Escherichia coli is represented by ++--, the Klebsiella-Enterobacter group is represented by --++ , and an intermediate form, Citrobacter freundii, is represented by -+-+ .

Cowan et al. (7) published a classification of Klebsiella, subdividing the genus into six categories, including pathogenic $K$. pneumoniae and saprophytic $K$. aerogenes. Duguid (8) reported that $K$. aerogenes was fimbriated whereas $K$. pneumoniae was not, further adding to the separation. In 1973 , Fallon (12) reported $K$. aerogenes as the predominant species isolated from Klebsiella-contaminated sputum samples, but he determined that it was seldom pathogenic. $K$. pneumoniae was isolated from only $2.3 \%$ of the sputum samples cultured, but better than half of those isolated were considered to be disease related. Fallon primarily utilized the taxonomic scheme of Cowan et al. (7) and Cowan and Steel (6) in identification of the isolates. Bascomb et al. (3) also supported the separation of $K$. aerogenes from $K$. pneumoniae.

Cowan (5) has recently published a revision of the 1960 taxonomic scheme, which reiterates the need for six species or groups instead of the three that $\emptyset$ rskov (17) designated in Bergey's Manual. Cowan designated one species Klebsiella aerogenes, which other workers consider to be synonymous with $K$. pneumoniae $(10,11$, $17)$. His supporters have found that $K$. aerogenes is saprophytic, serologically falls into all types, and is $\mathrm{MR}^{-}$and $\mathrm{VP}^{+}$. On the other hand, the $K$. pneumoniae (sensu stricto) of Cowan is pathogenic, serologically only type 3 , and $\mathrm{MR}^{+}$ and VP-. Thus, the consolidation of the two species, as has been done by Ewing (11) and Orskov (17), offers a degree of inconsistency in IMViC results.

Johnson et al. (13), in a recent work on numerical taxonomy of Enterobacteriaceae, used strains designated by other sources as $K$. aerogenes and $K$. pneumoniae. Results of IMViC and other distinguishing tests were inconclusive, and they classified both clusters under the single species $K$. pneumoniae.

With the advent of more sophisticated monitoring of aquatic systems, klebsiellae have become important both as indicator organisms and as potential water-borne pathogens $(15,18)$. Although clinical laboratories may not routinely use MR and VP in their determinations, aquatic microbiologists have found IMViC to be useful in confirmation of presence of fecal coliforms (2). The published inconsistencies in the IMViC results for $K$. pneumoniae are confusing, particularly since mouse virulence tests and serological typing are not done routinely in aquatic monitoring, and work recently pub- 
TABLE 1. IMViC reactions for Klebsiella pneumoniae and Klebsiella aerogenes as published between 1960 and 1974

\begin{tabular}{|c|c|c|}
\hline \multirow[b]{2}{*}{ Reference } & \multicolumn{2}{|c|}{ IMViC reactions for: } \\
\hline & $\begin{array}{c}K . \\
\text { pneumoniae }\end{array}$ & $\begin{array}{c}K . \\
\text { aerogenes }\end{array}$ \\
\hline $\begin{array}{l}\text { Cowan (5) } \\
\text { Johnson et al. (13) } \\
\text { Cowan et al. (7) } \\
\text { Ewing (11) } \\
\text { Lennette et al. (14) } \\
\text { Orskov (17) } \\
\text { Ales Reinlein et al. (1) } \\
\text { Burrows (4) }\end{array}$ & 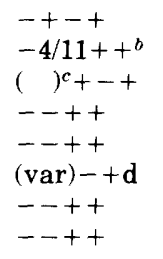 & $\begin{array}{l}--++ \\
-3 / 52 / 5+ \\
--++ \\
c \\
c \\
c \\
c \\
c\end{array}$ \\
\hline
\end{tabular}

${ }^{a} K$. aerogenes is not considered a valid taxon by Orskov (17) and other workers.

${ }^{b} 4 / 11$ indicates the number $+/$ number tested.

$c$ Information not given.

lished indicates that aquatic-borne klebsiellae fitting Cowan's and Fallon's descriptions for $K$. aerogenes are pathogenic for mice (15). Although there is no argument regarding the fact that $K$. aerogenes is properly relegated to the genus, the difference in MR and VP results may lead to misidentification of aquatic isolates.

It is suggested that aquatic microbiologists associated with monitoring Klebsiella species utilize other tests, particularly ornithine decarboxylation and motility, for identification of suspected isolates. This should reduce the possibility of misidentification until the taxonomic question can be resolved.

\section{ACKNOWLEDGMENT}

This work was supported by research grant R-803341-01-0 from the U.S. Environmental Protection Agency.

\section{REPRINT REQUESTS}

Address reprint requests to: Dr. Ivan L. Roth, Department of Microbiology, The University of Georgia, Athens, Ga. 30602 .

\section{LITERATURE CITED}

1. Ales Reinlein, J. M., E. Zornoza-Boy, and F. Cachon Garcia. 1972. El Grupo Klebsiella-Enterobacter. Rev. Clin. Esp. 126:289-296.

2. American Public Health Association. 1971. Standard methods for the examination of water and waste water, 13th ed. American Public Health Association, New York.

3. Bascomb, S., S. P. Lapage, W. R. Willcox, and M. A. Curtis. 1971. Numerical classification of the tribe Klebsielleae. J. Gen. Microbiol. 66:279-295.

4. Burrows, W. 1973. Textbook of microbiology, 20th ed. p. 479-481. W. B. Saunders Co., Philadelphia.

5. Cowan, S. T., and K. J. Steel. 1965. Manual for the identification of medical bacteria, 2nd ed., p. 103-112. Cambridge University Press, New York.

6. Cowans, S. T., and K. J. Steel. 1965. Manual for the identification of medical bacteria, p. 61-82. Cambridge University Press, New York.

7. Cowan, S. T., K. J. Steel, Constance Shaw, and J. P. Duguid. 1960. A Classification of the Klebsiella Group. J. Gen. Microbiol. 23:601-612.

8. Duguid, J. P. 1959. Fimbriae and adhesive properties in Klebsiella strains. J. Gen. Microbiol. 21:271-286.

9. Duncan, D. W., and W. E. Razzell. 1972. Klebsiella biotypes among coliforms isolated from forest environments and farm produce. Appl. Microbiol. 24:933938.

10. Edwards, P. R., and W. H. Ewing. 1972. Identification of Enterobacteriaceae, rev. 3rd ed. Burgess Publishing Co., Minneapolis.

11. Ewing, W. H. 1973. Differentiation of Enterobacteriaceae by biochemical reactions, revised ed. Center for Disease Control publication no. 75-8270. Public Health Service. U.S. Government Printing Office, Washington, D.C.

12. Fallon, R. J. 1973. The relationship between the biotype of Klebsiella species and their pathogenicity. J. Clin. Pathol. 26:523-528.

13. Johnson, R., R. R. Colwell, R. Sakazaki, and K. Tamura. 1975. Numerical taxonomy study of the Enterobacteriaceae. Int. J. Syst. Bacteriol. 25:12-37.

14. Lennette, E. H., E. H. Spaulding, and J. P. Truant (ed.). 1974. Manual of clinical microbiology, 2nd ed., American Society for Microbiology, Washington, D.C.

15. Matsen, J. M., J. A. Spindler, and R. O. Blosser. 1974. Characterization of Klebsiella isolates from natural receiving waters and comparison with human isolates. Appl. Microbiol. 28:672-678.

16. Nunez, W. J., and A. R. Colmer. 1968. Differentiation of Aerobacter-Klebsiella isolated from sugar cane. Appl. Microbiol. 16:1875-1878.

17. Ørskov, I. 1974. Genus VI. Klebsiella Trevisan 1885,105 Nom. cons. Opin. 13, Jud. Comm. 1954, 152, p. 321324. In R. E. Buchanan and N. E. Gibbons (ed.), Bergey's manual of determinative bacteriology, 8th ed. The Williams \& Wilkins Co., Baltimore.

18. Vasconcelos, G. J. 1972. The detection and significance of fecal coliform in industrial waste. In R. H. Bordner and B. J. Carroll (ed.), Proceedings of the Seminar on the Significance of Fecal Coliform in Industrial Wastes. Environmental Protection Agency, Office of Enforcement, National Field Investigation Center, Denver. 